\title{
GIS-BASED FLOOD HAZARD MAPPING USING HEC-RAS MODEL: A CASE STUDY OF LOWER MEKONG RIVER, CAMBODIA
}

\author{
Vanthan KIM ${ }^{1}$, Sarintip TANTANEE ${ }^{2}$, Wayan SUPARTA ${ }^{3}$ iD
}

DOI: 10.21163/GT_2020.151.02

\begin{abstract}
:
Rivers are the main water sources for human and animals' lives. Unfortunately, they have been frequently damaged by flooding. Flooding has affected and threatened not only human's lives and infrastructures but also the environmental capital. This study aims to determine the application of flood frequency analysis integrated with the GIS and HECRAS models to prepare a multi-return period flood hazard map in the Lower Mekong River of Cambodia. A 30-year peak discharge (Kampong Cham gauging station) with a multireturn period of $10,20,50$, and 100-years was estimated by using four distributions analysis. An EasyFit software is used to test the best distribution for the input of the HECRAS model to prepare the estimation of the corresponding floodplain areas. The results showed that Log-Pearson III distribution analysis of the return period of 10, 20, 50, 100 years is the best fits with the $52,208 \mathrm{~m}^{3} / \mathrm{s}, 54,990 \mathrm{~m}^{3} / \mathrm{s}, 59,381 \mathrm{~m}^{3} / \mathrm{s}$, and $62,194 \mathrm{~m}^{3} / \mathrm{s}$, respectively. The HEC-RAS calibration indicated a good agreement with observed data discharge 2011 and 2013. While the simulation model shows the return period of floods 10 and 20 years for the predicted depth of flooding is stable compared to the flood peaks of 2011 and 2013 discharges, but the conditions of other flood return periods are not stable. Overall, HEC-RAS with its flood hazard map is a model that can estimate the level of flood depth in the Lower Mekong River, Cambodia and is useful in providing information about the depth and characteristics of floods for river communities.
\end{abstract}

Key-words: Flood Hazard Map, GIS, HEC-RAS, Flood Frequency analysis, Mekong River

\section{INTRODUCTION}

Over the last decades, the flood has been the most common natural disaster worldwide, constructing many negative environmental and socio-economic consequences on people, infrastructures, properties, and indirectly impact the country's economy (Kheradmand et al., 2018). The conservative flood management approach focusing on structural flood mitigation measures have now been shifted to a risk-based flood mitigation concept (Romali et al., 2018). Furthermore, the severity of flood hazard around the world requires to continue prevention to reduce their impact (Azouagh et al., 2018). Because it is the most widespread, frequent, and costly natural disaster for human societies (Mihu-Pintilie et al., 2019). Each year, more than 140 million people across the world are affected by floods (OECD, 2016). Flood hazard is the probability of a flood event will take place (Vojtek \& Vojtekova, 2016).

Flood modeling is very important for flood hazard assessment to show the magnitude of a flood with a convincing exceeded probability (Azouagh et al., 2018), while the purpose

\footnotetext{
${ }^{1,2}$ Naresuan University, Department of Civil Engineering, Faculty of Engineering, Phitsanulok 6500, Thailand, Corresponding author: sarintipt@nu.ac.th

${ }^{3}$ Universitas Pembangunan Jaya, Department of Informatics, South Tangerang City, Banten 15413, Indonesia, Corresponding author: wayan.suparta@upj.ac.id ORCID 0000-0002-6193-1867
} 
of a vulnerability assessment is to provide hydrological characteristics to model the damage (Rahmati et al., 2016). Some researchers (e.g.,Shafapour et al., 2017; Mihu-Pintilie \& Nicu, 2019) applied a GIS-based approach to conduct flood hazard mapping with different parameters (i.e. land use, land cover, DEM, soil, river network, and slop). Mostly, coupling GIS and hydraulic models (Haidu, 2016) have been recommended for studying flood analysis and flood prediction (Győri et al., 2016; Haidu et al., 2017; Vojtek et al., 2019). A combination of GIS (Geographic Information System) and HEC-RAS (Hydrologic Engineering Center-River Analysis System) has a great capability in the simulation of flood hazard maps. HEC-RAS is one of the most commonly used models to analyze channel flow and floodplain delineation (Maskong, 2019). River flood hazard mapping was first initiated in 1988 in the United States by the Hydrologic Engineering Centre (HEC) of the U.S. Army Corps of Engineers (USACE, 2018). The HEC-RAS model was found to give a good performance where the simulated results for both studies showed a close agreement with observed water surfaces.

In Cambodia, floods caused by the Mekong River in 2000 and 2011 killed 250 people, affected 350,000 households of over 1.5 million people, causing 52,000 households to be evacuated, costing the economy 521,000 million US dollars. These floods were ranked as the worst natural disasters in Cambodia over the last 70 years (CFE-DM, 2017). Moreover, report the Cambodian floods of 2013, which affected 20 out of 24 provinces, 377,354 households, claiming 168 lives, and forcing 31,314 households to be evacuated to safer areas (Rishiraj et al., 2015; Vichet et al., 2019). Mochizuki et al. (2015), who study the assessment of the natural disaster of flood and cyclone risks to public and private buildings including educational structures, health facilities, and housing, estimates that the total direct economic damage ranges from approximately 304 million US dollars for a 5-year return period event, to 2.26 billion US dollars for a 1000 -year return period event. Furthermore, the annual records by the National Committee of Disaster Management of Cambodia (1996 to 2018) as well as (Yu et al., 2019) review of CRED, 2014, showed that extreme flooding from the Mekong River mostly affected the country in 1978, 1991, 1994, 1996, 2000-2002, 2011, and 2013. Likewise, Cambodia Disaster and Risk Profile (EM-DAT) 2017, who study floods caused by drought and storm based on frequency, mortality and economic issues, observe that flooding induced more complicated impact than drought and storm (CRED, 2019).

Flood hazard map is considered an important tool for tackling these problems. The study aims to prepare a flood hazard map that integrates flood inundation areas, flood extent, and flood depth in the study area. HEC-RAS and GIS-based methods are the main components in analyzing flood hazards of the lower Mekong River, Cambodia. The scope of the study is focused on the river floods, where investigate the ability of methods applied to design flood hazard maps and the length of the data series.

\section{STUDY AREA AND DATA}

Cambodia is one of the countries in South-East Asia located between 102.350 and 107.620 longitude and 9.910 and 14.690 latitudes. The total area is $181,035 \mathrm{~km}^{2}, 97.5$ percent of which is the land while 2.5 percent is a water body (Vichet et al., 2019). The Mekong River is one of the world's longest river systems, flowing 4,909 km through six countries: China, Myanmar, Thailand, Lao PDR, Cambodia, and Vietnam, having a basin area of $795,000 \mathrm{~km}^{2}$, and a mean annual discharge of $14,500 \mathrm{~m}^{3} / \mathrm{s}$ or $475 \mathrm{~km}^{3} /$ year. The flows are of a very large difference during the wet (June to October) and dry (November to May) seasons (Ang \& Oeurng, 2018). 
This study aims to develop a return period-based flood hazard map using the GIS and HEC-RAS models in the part of Kampong Cham $\left(1,258 \mathrm{~km}^{2}\right)$, Tboung Khmum $\left(87 \mathrm{~km}^{2}\right)$, and Kandal $\left(518 \mathrm{~km}^{2}\right)$ province and Phnom Penh $\left(85 \mathrm{~km}^{2}\right)$ city. The river division (Fig. 1) starts from the Mekong upstream Kampong Cham (KC) and reaches Chruy Changvar (CC) gauging station (Phnom Penh City), with the area of $1,948 \mathrm{~km}^{2}$ and length $103.53 \mathrm{~km}$ in Cambodia.

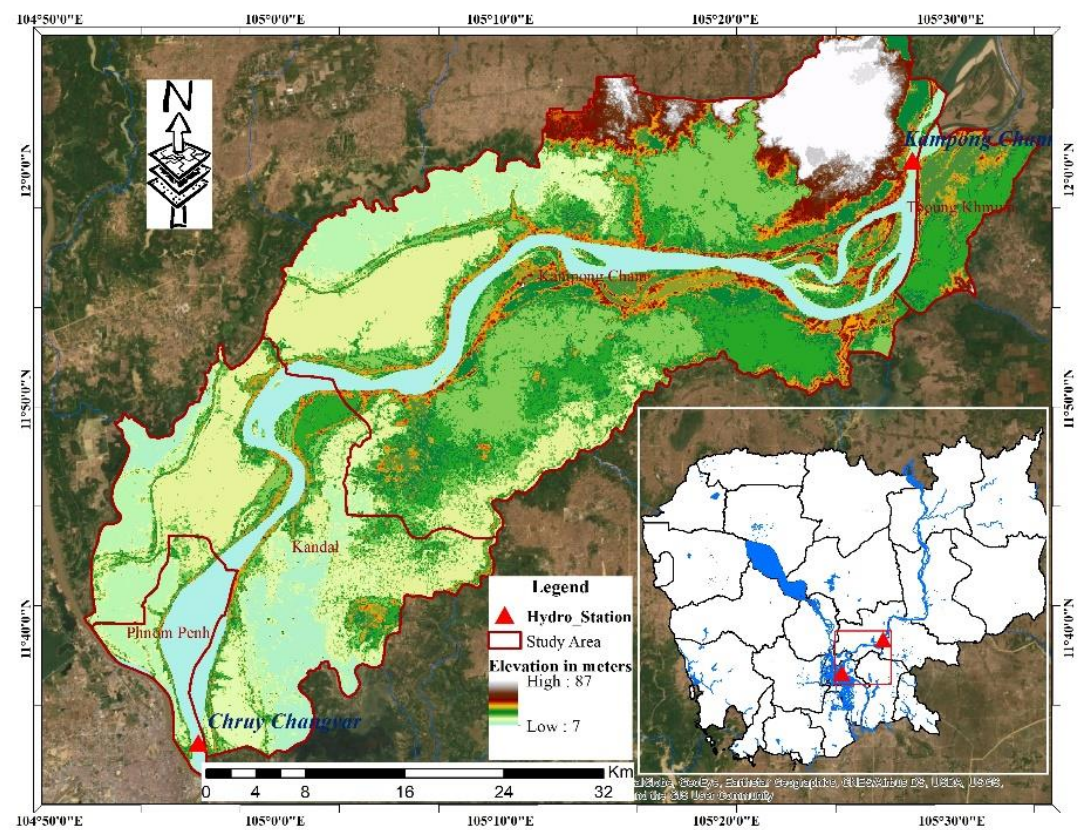

Fig. 1. Location of the study area (Source: authors).

Peak discharge in 30 years is collected from the Department of Meteorology and River Works, Cambodia. The peak discharge is used to calculate the different return periods of 10, 20, 50, and 100-years. Hence, the 30m resolution of Advanced Spaceborne Thermal Emission and Radiometer (ASTER) Digital Elevation Model (DEM) was downloaded free from the U.S Geological Survey website (https://earthexplorer.usgs.gov/) in order to extract basin geometry, stream networks, river geometry, Triangular Irregular Network (TIN), and 100 cross-sections.

\section{METHODOLOGY}

\subsection{Flood Frequency Analysis}

To analyze the extreme values of different return periods 10, 20, 50, and 100-years using observed maximum historical discharge, a variety of methods can be applied, i.e. Log-Pearson type III, Log-Normal, Normal, and Gumbel's distribution (Tanaka et al., 2017; Farooq et al., 2018; Bhat et al., 2019). Moreover, the estimation of peak discharge is an important step for selecting flood events and different return periods to input model processing. 
In this study, Log-Pearson type III, Log-Normal, Normal, and Gumbel's distribution were used in flood frequency analysis. The EasyFit software was used to select the base flood value to identify the peak flood of various historical records. 30 annual peak discharges of Kampong Cham station (ID: 198,02 and coordinate, X: 551,341, Y: 1,327,363) between 1989 and 2018 were used. The goodness of fit test (GOF) of Kolmogorov, Anderson, and Chi-Squared were employed to analyze and estimate the bestfitted distribution.

\subsection{GIS and HEC-RAS Modeling}

GIS provides a broad range of tools for determining areas affected by floods or for forecasting areas likely to be flooded due to high river water levels (Klemešová et al., 2014). A DEM offers the most common way of showing topographic information and even enables the modeling of flow across topography; a controlling factor in distributed models of landform processes (Toosi et al., 2019).

HEC-RAS is a widely used hydraulic software tool developed by the U.S Army Corps of Engineers (USACE, 2018). HEC-RAS employs 1-D flood routing in both steady and unsteady flow conditions by applying an implicit-forward finite difference scheme between successive sections of flexible geometry. The steady flow scheme is based on the solution of the 1-D energy equation or the momentum equation between two successive crosssections (USACE, 2018). The energy equation is written as follows (Echogdali et al., 2018, p. 963):

$$
Z_{2}+Y_{2}+\frac{a_{2} V_{2}^{2}}{2 g}=Z_{1}+Y_{1}+\frac{a_{1} V_{2}^{2}}{2 g}+h_{e}
$$

where $Z_{1}$ and $Z_{2}$ are the elevations of the main channel inverts, $Y_{1}$ and $Y_{2}$ are the depths of water at cross-sections, $\mathrm{V}_{1}, \mathrm{~V}_{2}$ is the average velocities (total discharges/total flow area), a1, a2 are the velocity weighting coefficients, that account for non-uniformity of the velocity distribution over the crosssection, g: gravitational acceleration, and he: is the energy head loss.

The cross-section sub-division for the water conveyance is calculated within each reach using the following equations:

$$
\mathrm{Q}=\mathrm{KS}_{\mathrm{f}}^{1,2} \text {, while } \mathrm{K}=\frac{1.486}{\mathrm{n}} \mathrm{AR}^{2 / 3}
$$

where $\mathrm{K}=$ conveyance for subdivision, $\mathrm{n}=$ Manning roughness coefficient, $\mathrm{A}=$ flow area subdivision, $\mathrm{R}=$ hydraulic radius for subdivision (wetted area/wetted perimeter), and $\mathrm{S}_{\mathrm{f}}=$ friction slope.

DEM was used as input data to generate a watershed and drainage network in RAS Mapper. The channel, bank stations, flow direction, and cross-section cut lines were prepared in RAS Mapper and exported to the HEC-RAS model. An upstream (Kampong Cham) station of Lower Mekong River was selected for data input. Moreover, the multi return periods of the peak floods were obtained from Log-Pearson III and used as an input to the model in order to simulate results for each cross-section. At the same time, water surface profiles were run in the model for 10, 20, 50, and 100-years. After running input data in the HEC-RAS model, the outputs were exported to GIS in the format of the RAS GIS Export file. GIS was used to generate flood depth mapping for multi return periods. The overall methodology flow chart is shown in (Fig. 2). 


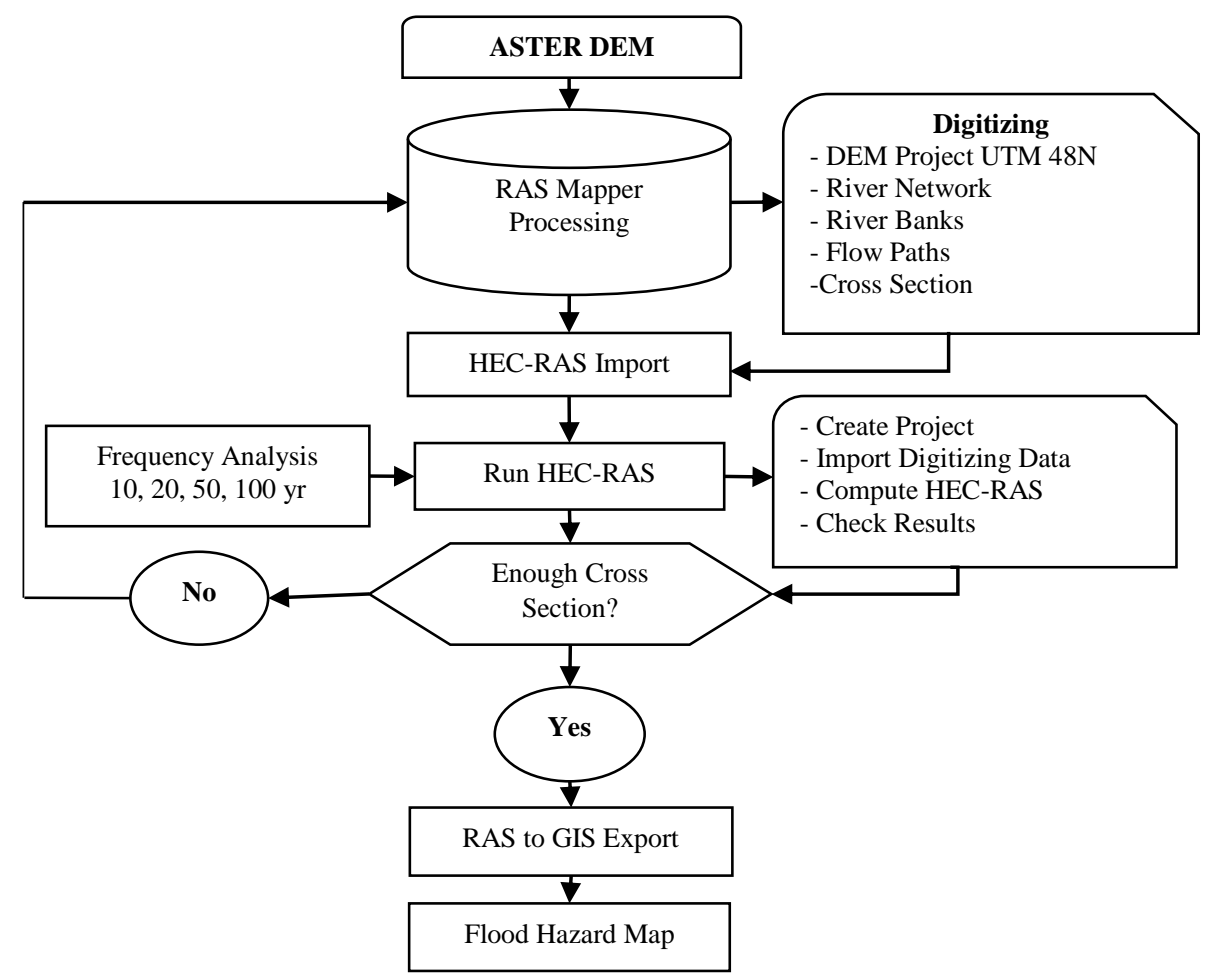

Fig. 2. Methodology framework of flood hazard mapping

\subsection{Calibration of HEC-RAS Model}

The calibration of the model has used three indicators including Nash-Sutcliffe model efficiency (NSE), percent bias (PBIAS), and coefficient of determination $\left(\mathrm{R}^{2}\right)$ were computed using daily average flow, as standard show in (Table 1) (USACE, 2018)

$$
\begin{gathered}
\text { NSE } \left.=1-\frac{\sum_{\mathrm{i}=1}^{\mathrm{n}}\left(\mathrm{Q}_{\mathrm{obs}}-\mathrm{Q}_{\text {sim }_{\mathrm{i}}}\right)^{2}}{\left.\sum_{\mathrm{i}=1}^{\mathrm{n}}\left(\mathrm{Q}_{\mathrm{obs}}{ }_{\mathrm{i}}-\mathrm{Q}_{\mathrm{obs}}\right)_{\mathrm{i}}\right)^{2}}\right] \\
\text { PBIAS }=\left[\frac{\sum_{i=1}^{n}\left(Q_{i}^{o b s}-Q_{i}^{\text {sim }}\right) \times 100}{\sum_{i=1}^{n}\left(Q_{i}^{o b s}\right)}\right] \\
R^{2}=\frac{\sum\left(\left(Q_{\operatorname{sim}}(t)-\overline{Q_{\text {sim }}}\right)\left(Q_{o b s}(t)-\bar{Q}_{o b s}\right)\right)^{2}}{\sum\left(Q_{\operatorname{sim}}(t)-\overline{Q_{\operatorname{sim}}}\right)^{2} \sum\left(Q_{o b s}(t)-\overline{Q_{o b s}}\right)^{2}}
\end{gathered}
$$


where $\mathrm{Q}_{\operatorname{sim}(\mathrm{t})}$ and $\mathrm{Q}$ obs(t) are the simulated and observed discharges at time step $\mathrm{t}$, and $\overline{Q_{\text {sim }}}$ and $\overline{Q_{o b s}}$ are the simulated and observed average discharges.

Table 1.

Performance ratings for summary statistics.

\begin{tabular}{|l|c|c|c|}
\hline Performance Rating & NSE & PBIAS & $\mathrm{R}^{2}$ \\
\hline Very Good & $0.65<\mathrm{NSE} \leq 1.00$ & PBIAS $< \pm 15$ & $0.65<\mathrm{R}^{2} \leq 1.00$ \\
\hline Good & $0.55<\mathrm{NSE} \leq 0.65$ & $\pm 15 \leq \mathrm{PBIAS}< \pm 12$ & $0.55<\mathrm{R}^{2} \leq 0.65$ \\
\hline Satisfactory & $0.40<\mathrm{NSE} \leq 0.55$ & $\pm 20 \leq \mathrm{PBIAS}< \pm 30$ & $0.70<\mathrm{R}^{2} \leq 0.55$ \\
\hline Unsatisfactory & $\mathrm{NSE} \leq 0.40$ & PBIAS $\geq \pm 30$ & $\mathrm{R}^{2} \leq 0.40$ \\
\hline
\end{tabular}

Source: US Army Corps of Engineers (USACE, 2018)

\section{RESULTS AND DISCUSSIONS}

\section{1 Flood Frequency Analysis}

The peak discharge for 10, 20, 50, and 100-year return periods, is calculated using Log-Pearson III, Log-Normal, Normal and Gumbel distributions as indicated in Table 2. The Easyfit software found that the value of predicted peak flood using Log-Pearson 3 distribution is the best goodness of fit. The predicted maximum flood using Gumbel's is the highest as, compared to Log-N and Normal. The smallest values were obtained by LogPearson III.

Table 2.

Return periods based on Log-P3, Log-N, Normal, and Gumbel distributions analysis.

\begin{tabular}{|c|c|c|c|c|}
\hline \multirow{2}{*}{$\begin{array}{c}\text { Return Period } \\
\text { (Years) }\end{array}$} & \multicolumn{4}{|c|}{ Estimated Peak Discharge in Deference Distribution at KC Station $\left(\mathrm{m}^{3} / \mathrm{s}\right)$} \\
\cline { 2 - 5 } & Log-P3 & Log-Normal & Normal & Gumbel \\
\hline 10 & 52208 & 50701 & 50242 & 51523 \\
\hline 20 & 54990 & 55158 & 53698 & 55160 \\
\hline 50 & 59381 & 57459 & 55376 & 59869 \\
\hline 100 & 62194 & 61510 & 58171 & 63397 \\
\hline
\end{tabular}

Table 3.

The performance ranking based on Kolmogorov, Anderson and Chi-Squared goodness of fit Test.

\begin{tabular}{|l|c|c|c|c|c|c|}
\hline \multirow{2}{*}{ Distribution } & \multicolumn{2}{|c|}{ Kolmogorov } & \multicolumn{2}{c|}{ Anderson } & \multicolumn{2}{c|}{ Chi-Squared } \\
\cline { 2 - 7 } & Statistic & Rank & Statistic & Rank & Statistic & Rank \\
\hline Log-Pearson III & 0.0933 & 1 & 0.3371 & 1 & 0.2096 & 1 \\
\hline Normal & 0.1053 & 2 & 0.4226 & 2 & 0.5162 & 2 \\
\hline Lognormal & 0.1096 & 3 & 0.5972 & 3 & 2.0160 & 3 \\
\hline Gumbel Max & 0.1419 & 4 & 1.4984 & 4 & 3.6242 & 4 \\
\hline
\end{tabular}

Table 3 indicates the performance ranking based on Kolmogorov, Anderson and ChiSquared test. Log-Pearson III is ranked first in terms of performance, followed by Log-N, Normal, and Gumbel distribution. The ranking is based on the p-value. A p-value closer to 1 indicates a goodness of fit distribution. The highest p-value of goodness of fit test is 0.1419 and the lowest is 0.0933. Based on the results (Fig. 3), Log-Pearson III distribution was put into HEC-RAS hydraulic model. The peak flood estimated for 10, 20, 50, and 100years are $52,208 \mathrm{~m}^{3} / \mathrm{s}, 54,990 \mathrm{~m}^{3} / \mathrm{s}, 59,381 \mathrm{~m}^{3} / \mathrm{s}$, and $62,194 \mathrm{~m}^{3} / \mathrm{s}$ respectively of Kampong Cham gauge station. 


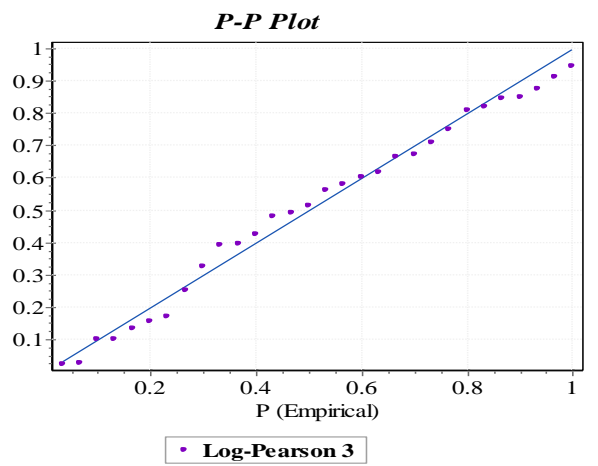

Fig. 3. Plot delineation goodness best fit of Log-Pearson III.

\subsection{Performance Calibrated Model Simulation of Year 2011 and 2013}

During the 2011 and 2013 flood events, there was a recorded highest hydrograph at the study area. The peak discharge of the observed hydrograph in $\mathrm{KC}$ upstream was 50,967 $\mathrm{m}^{3} / \mathrm{s}$, whereas that in $\mathrm{CC}$ downstream was only $39,612 \mathrm{~m}^{3} / \mathrm{s}$. Based on this approach and simulation, an upstream hydrograph was generated and the recorded hydrograph of the downstream from the HEC-RAS model to validate the hydrograph recorded at the CC station. These results were confirmed to correct this flood hydrograph; the new hydrograph was the simulated during the years 2011 and 2013 to adjust the peak observed hydrograph showed in (Fig. 4 and Fig. 5).
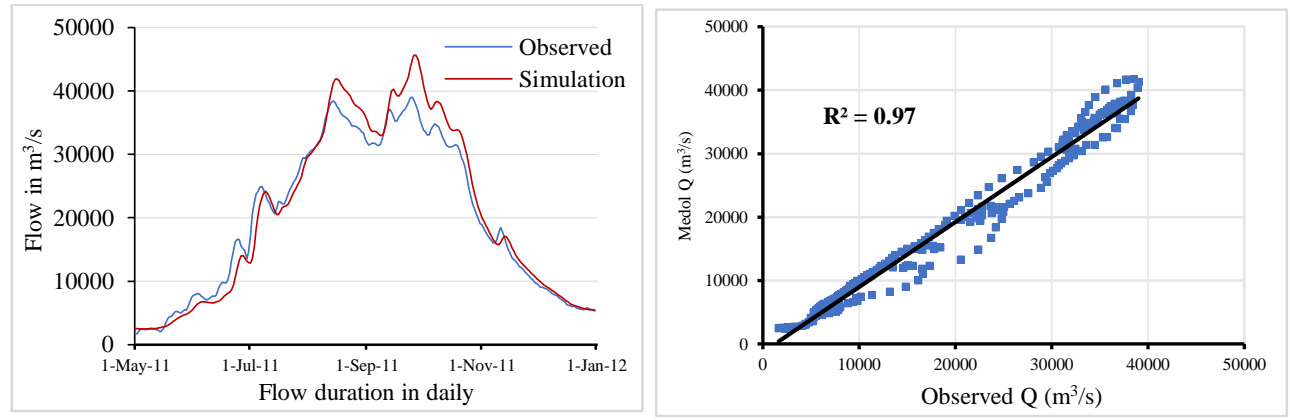

Fig. 4. Observed and simulated flow hydrograph at the downstream year 2011.
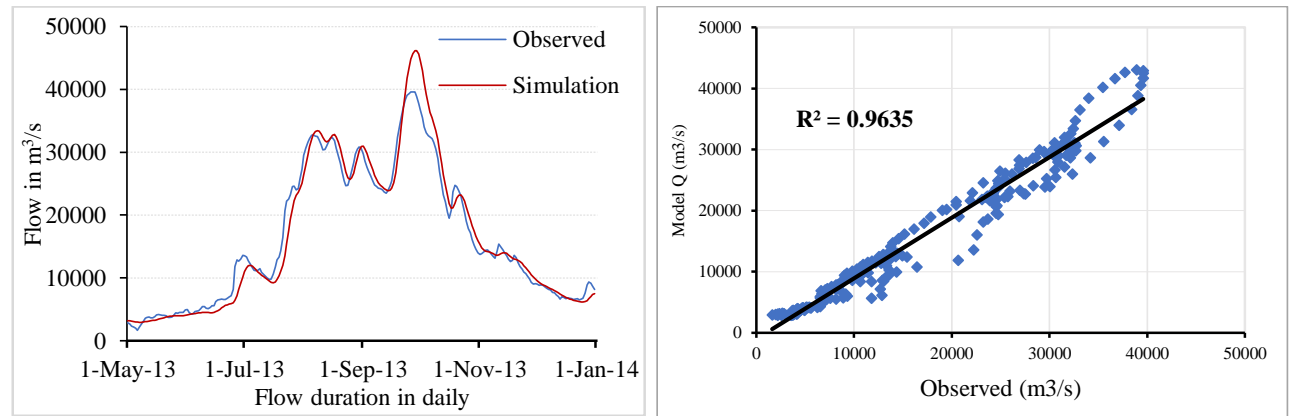

Fig. 5. Observed and simulated flow hydrograph at the downstream year 2013. 
Hydraulic model performance (Table 4) was tested using NSE, PBIAS, and $\mathrm{R}^{2}$ statistics with values of the year $2011(0.91,15.14$, and 0.97$)$ and the year $2013(0.90$, 15.38, and 0.96), respectively. The calibration with simulated flood depths from the HECRAS flow model shows a fairly good agreement with observations where their relationship shows very strong.

Table 4.

Model performance of the river discharge at the stations during calibration.

\begin{tabular}{|c|c|c|c|c|c|c|}
\hline Years & Simulation period & $\begin{array}{c}\text { Roughness } \\
\text { coefficient } \\
\text { Manning's n }\end{array}$ & $\begin{array}{c}\text { Boundary } \\
\text { condition } \\
\text { Normal depth }\end{array}$ & NSE & PBIAS & $\mathrm{R}^{2}$ \\
\hline 2011 & May-Dec, 2011 & 0.035 & 0.001 & 0.91 & 15.14 & 0.97 \\
\hline 2013 & May-Dec, 2013 & 0.035 & 0.001 & 0.90 & 15.38 & 0.96 \\
\hline
\end{tabular}

\section{3 Flood Hazard Mapping}

An HEC-RAS hydraulic modeling set-up was created to generate the water discharge due to the 2011 and 2013 flood and subsequently, the flood map for various returns simulated the 2011 and 2013 flood and the simulated 10, 20, 50 and 100-year periods. The comparison between the return periods is presented. The flood depth was reclassified to three levels such as 0.001 to 3 meters, 3 to 6 meters, 6 to 9 meters, and 9 to 14 meters, to identify little or no flood, medium flood, and high flood events. The results are presented in Tabel 5.

Table 5.

Flood depth extend the area of the return period 10, 20, 50, and 100-year.

\begin{tabular}{|c|c|c|c|c|c|}
\hline \multirow{2}{*}{\multicolumn{2}{|c|}{ Flood Depth (m) }} & \multicolumn{4}{|c|}{ Flood depth deference return periods (RP) study area $\left(\mathrm{km}^{2}\right)$} \\
\cline { 3 - 6 } \multicolumn{2}{|c|}{} & 10 -year & 20 -year & 50 -year & 100 -year \\
\hline$<3(\mathrm{~m})$ & very low & 156 & 137 & 131 & 128 \\
\hline $3-6(\mathrm{~m})$ & low & 465 & 423 & 375 & 348 \\
\hline $6-9(\mathrm{~m})$ & medium & 741 & 727 & 788 & 812 \\
\hline 9-12(m) & high & 294 & 371 & 358 & 353 \\
\hline$>12(\mathrm{~m})$ & very high & 21 & 27 & 45 & 66 \\
\hline
\end{tabular}

The following maps are the simulation of the results steady from flood return period 10, 20, 50, and 100-year, indicated as increase like (Fig. 6). The presented is classified as the layer based on depth values as per the criteria mentioned in Table 3. For floodplain exposure to the simulated flood depth and extent, 'Intersect' flood depth layer (vector format) with the flood depth layer. Then summarize the exposed flood depth in the form of graphs/maps while the river depth increases the highest from return period 10, 20, 50, and 100 as like $12.86 \mathrm{~m}, 13.10 \mathrm{~m}, 13.46 \mathrm{~m}$, and $13.69 \mathrm{~m}$. The following graph shows landcover exposure to the deference of flood return period 10, 20, 50, and 100-year events in the study. 

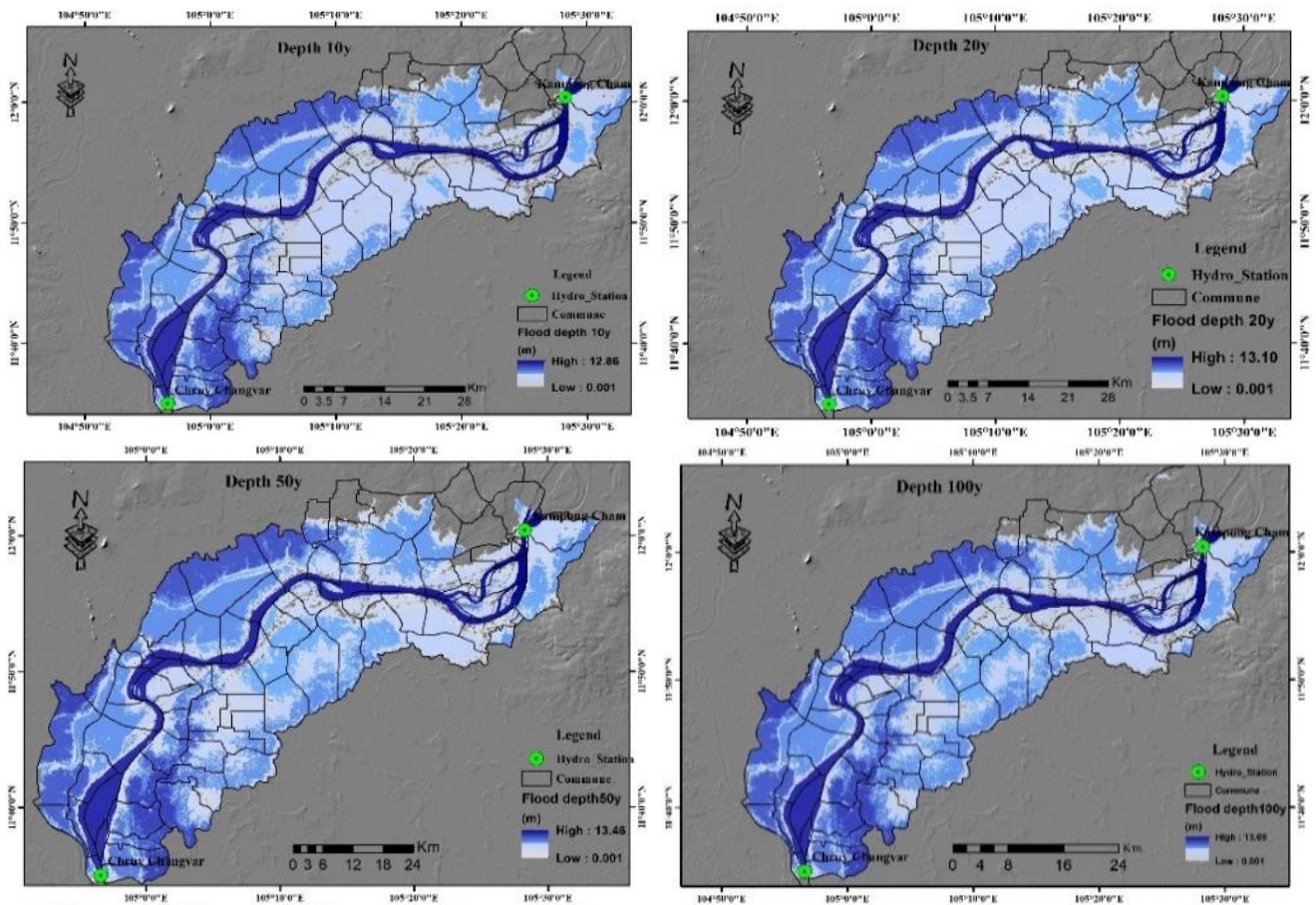

Fig. 6. Simulated flood depth area at the return period $\mathrm{Q}_{10 \mathrm{yr}}=52208 \mathrm{~m}^{3} / \mathrm{s}, \mathrm{Q}_{20 \mathrm{yr}}=54990 \mathrm{~m}^{3} / \mathrm{s}, \mathrm{Q}_{50 \mathrm{yr}}=59381 \mathrm{~m} 3 / \mathrm{s}$, and $\mathrm{Q}_{100 \mathrm{yr}}=62194 \mathrm{~m}^{3} / \mathrm{s}$.

\section{CONCLUSIONS}

The study is attempted to apply the HEC-RAS version 5.0.7 and GIS version 10.5 with peak discharge through a steady flow analysis. Thus, the output of modeling was generated into flood extent and flood depth in ArcGIS. Flood hazard maps from 10, 20, 50, and 100year return period flood with the value of affected areas and flood depth along with the river study. According to the performance simulating of 2011 and 2013 with the downstream station, the value of NSE, PBIAS, and $\mathrm{R}^{2}$ statistics with values of the year $2011(0.91,15.14$, and 0.97) and year $2013(0.90,15.38$, and 0.96) accuracy.

To construct a flood hazard map for the highest flood-affected area is the applicated model and validation value of Manning's $\boldsymbol{n} 0.035$ for simulating 1D flood depth. Simulated flood hazard map based on input peak discharge of multi flood return periods confirms that the simulated flood hazard areas at 10, 20, 50, and 100-years are $52208 \mathrm{~m}^{3} / \mathrm{s}, 54990 \mathrm{~m}^{3} / \mathrm{s}$, $59381 \mathrm{~m}^{3} / \mathrm{s}$, and $62194 \mathrm{~m}^{3} / \mathrm{s}$ almost identical to the 2011 and $2013\left(50295 \mathrm{~m}^{3} / \mathrm{s}\right.$ and 50295 $\mathrm{m}^{3} / \mathrm{s}$ ) observed peak discharge. The simulation suggests that most of the flood depth areas of the 10 and 20-years flood return periods were also affected by the 2011 and 2013 historical floods. But 50 and 100-year flood return periods, the simulation was unstable. The flood hazard map can be utilized as a tool to identify the priority of the area for the planning of flood prevention, flood mitigation, and flood risk management.

This study presents the methodology for improving the awareness of the flood events. The aim was to reduce the damage from floods and provide a better quality of life in the 
study area. Coupling of GIS and hydraulic modeling provides a solution to sustainable flood protection and ensure a cleaner and safer environment. The present study mentions the successful combination of scientific and practical experiences to show the effectiveness of modeling techniques for engineering practice. In other words, it presents a successful functioning system of flood mitigation measures that increases sustainability and environmental protection of the territory. The outcome of the study could serve as an essential basis for a more informed decision and science-based recommendations in identifying river location and forming more effective policies in dealing with flood hazards.

\section{ACKNOWLEDGEMENTS}

The first author received the scholarship for his master's degree from the Royal Scholarship Project, under Her Royal Highness Princess Sirindhorn. I would like to express gratitude to Naresuan University, Thailand and Universitas Pembangunan Jaya, Indonesia for their provision of this special educational opportunity.

\section{R E F E R E N C E S}

Ang, R., \& Oeurng, C. (2018). Simulating streamflow in an ungauged catchment of Tonlesap Lake Basin in Cambodia using Soil and Water Assessment Tool (SWAT) model. Water Science, 32(1), 89-101. doi:10.1016/j.wsj.2017.12.002

Azouagh, A., El Bardai, R., Hilal, I., \& Stitou el Messari, J. (2018). Integration of GIS and HEC-RAS in Floods Modeling of Martil River (Northern Morocco). European Scientific Journal, ESJ, 14(12), 130. doi:10.19044/esj.2018.v14n12p130

Bhat, M. S., Alam, A., Ahmad, B., Kotlia, B. S., Farooq, H., Taloor, A. K., \& Ahmad, S. (2019). Flood frequency analysis of river Jhelum in Kashmir basin. Quaternary International, 507, 288-294. doi:https://doi.org/10.1016/j.quaint.2018.09.039

CFE-DM (2017). Disaster Management Reference Handbook-Cambodia 2017: Center for Excellence in Disaster Management \& Humanitarian Assistance.

CRED (2019). EM-DAT, The International Disaster Database, (Centre for Research on the Epidemiology of Disasters).

Echogdali, F. Z., Boutaleb, S., Elmouden, A., \& Ouchchen, M. (2018). Assessing Flood Hazard at River Basin Scale: Comparison between HECRAS-WMS and Flood Hazard Index (FHI) Methods Applied to El Maleh Basin, Morocco. Journal of Water Resource and Protection, 10(09), 957-977. doi:10.4236/jwarp.2018.109056

Farooq, M., Shafique, M., \& Khattak, M. S. (2018). Flood frequency analysis of river swat using Log Pearson type 3, Generalized Extreme Value, Normal, and Gumbel Max distribution methods. Arabian Journal of Geosciences, 11(9), 216. doi:10.1007/s12517-018-3553-z

Győri, M. M., Haidu, I., \& Humbert, J. (2016). Deriving the floodplain in rural areas for high exceedance Probability Having limited data source. Environmental Engineering and Management Journal, 15, 1879-1887. doi:10.30638/eemj.2016.201.

Haidu, I. (2016). What is Technical Geography - a letter from the editor. Geographia Technica, 11(1), 1-5. doi: $10.21163 / g t \_2016.111 .01$

Haidu, I., Batelaan, O., Crăciun, A.I., \& Domnița, M. (2017). GIS module for the estimation of the hillslope torrential peak flow. Environmental Engineering and Management Journal, 16(5), 1137-1144.

Kheradmand, S., Seidou, O., Konte, D., \& Barmou Batoure, M. B. (2018). Evaluation of adaptation options to flood risk in a probabilistic framework. Journal of Hydrology: Regional Studies, 19, 1-16. doi:https://doi.org/10.1016/i.ejrh.2018.07.001

Klemešová, K., Kolar, M., \& Andrasko, I. (2014). Using GIS in the Flood Management - Flood Maps (Troubky, Czech Republic). Geographia Technica, 9 (2), 44-53 
Maskong, H. (2019). Flood Hazard Mapping Using on-Site Surveyed Flood Map, Hecras V.5 and Gis Tool: A Case Study of Nakhon Ratchasima Municipality, Thailand. International Journal of GEOMATE, 16(54). doi:10.21660/2019.54.81342

Mihu-Pintilie, A., Cimpianu, C. I., Stoleriu, C. C., Perez, M. N., \& Paveluc, L. E. (2019). Using HighDensity LiDAR Data and 2D Streamflow Hydraulic Modeling to Improve Urban Flood Hazard Maps: A HEC-RAS Multi-Scenario Approach. Water, 11(9), 1832.

Mihu-Pintilie, A., \& Nicu, I. C. (2019). GIS-based Landform Classification of Eneolithic Archaeological Sites in the Plateau-plain Transition Zone (NE Romania): Habitation Practices vs. Flood Hazard Perception. Remote Sensing, 11(8), 915.

Mochizuki, J., Vitoontus, S., Wickramarachchi, B., Hochrainer-Stigler, S., Williges, K., Mechler, R., \& Sovann, R. (2015). Operationalizing Iterative Risk Management under Limited Information: Fiscal and Economic Risks Due to Natural Disasters in Cambodia. International Journal of Disaster Risk Science, 6(4), 321-334. doi:10.1007/s13753-0150069-y

OECD (2016). Financial Management of Flood Risk. Paris: OECD Publishing.

Rahmati, O., Zeinivand, H., \& Besharat, M. (2016). Flood hazard zoning in Yasooj region, Iran, using GIS and multi-criteria decision analysis. Geomatics, Natural Hazards and Risk, 7(3), 10001017. doi:10.1080/19475705.2015.1045043

Rishiraj, D., Senaka, B., \& Atiq, K. A. (2015). Assessing Gaps and Strengthening Early Warning System to Manage Disasters in Cambodia. doi:10.5595/idrim.2015.0104

Romali, N. S., Z., Y., \& Ismail, A. Z. (2018). Application of Hec-Ras and Arc Gis for Floodplain Mapping in Segamat Town, Malaysia. International Journal of GEOMATE, 14(43). doi:10.21660/2018.43.3656

Shafapour, T. M., Shabani, F., Neamah, J. M., Hong, H., Chen, W., \& Xie, X. (2017). GIS-based spatial prediction of flood prone areas using standalone frequency ratio, logistic regression, weight of evidence and their ensemble techniques. Geomatics, Natural Hazards and Risk, 8(2), 1538-1561. doi:10.1080/19475705.2017.1362038

Tanaka, T., Tachikawa, Y., Ichikawa, Y., \& Yorozu, K. (2017). Impact assessment of upstream flooding on extreme flood frequency analysis by incorporating a flood-inundation model for flood risk assessment. Journal of Hydrology, 554, 370-382. doi:https://doi.org/10.1016/j.jhydrol.2017.09.012

Toosi, A. S., Calbimonte, G. H., Nouri, H., \& Alaghmand, S. (2019). River basin-scale flood hazard assessment using a modified multi-criteria decision analysis approach: A case study. Journal of Hydrology, 574, 660-671. doi:10.1016/j.jhydrol.2019.04.072

USACE (2018). Analyzing Flood Risk for Forecast Informed Reservoir Operations in the Russian River Watershed Using HEC-WAT. Institute for Water Resources Hydrologic Engineering Center: Institute for Water Resources Hydrologic Engineering Center.

Vichet, N., Kawamura, K., Phan Trong, D., Van On, N., Gong, Z., Lim, J., . . Bunly, C. (2019). MODIS-Based Investigation of Flood Areas in Southern Cambodia from 2002-2013. Environments, 6, 57. doi:10.3390/environments6050057

Vojtek, M., Petroselli, A., Vojtekova, J., \& Asgharinia, S. (2019). Flood inundation mapping in small and ungauged basins: sensitivity analysis using the EBA4SUB and HEC-RAS modeling approach.

Vojtek, M., \& Vojtekova, J. (2016). Flood hazard and flood risk assessment at the local spatial scale: a case study. Geomatics, Natural Hazards and Risk, 7(6), 1973-1992. doi:10.1080/19475705.2016.1166874

Yu, W., Kim, Y., Lee, D., \& Lee, G. (2019). Hydrological assessment of basin development scenarios: Impacts on the Tonle Sap Lake in Cambodia. Quaternary International, 503, 115-127. doi:10.1016/j.quaint.2018.09.023 